University of Nebraska - Lincoln

DigitalCommons@University of Nebraska - Lincoln

1996

\title{
Late Pliocene diatoms in a diatomite from Prydz Bay, East Antarctica
}

\author{
Albert D. Mahood \\ California Academy of Sciences, Golden Gate Park, San Francisco, California \\ John A. Barron \\ USGS
}

Follow this and additional works at: https://digitalcommons.unl.edu/usgsstaffpub

Part of the Earth Sciences Commons

Mahood, Albert D. and Barron, John A., "Late Pliocene diatoms in a diatomite from Prydz Bay, East Antarctica" (1996). USGS Staff -- Published Research. 265.

https://digitalcommons.unl.edu/usgsstaffpub/265

This Article is brought to you for free and open access by the US Geological Survey at DigitalCommons@University of Nebraska - Lincoln. It has been accepted for inclusion in USGS Staff -- Published Research by an authorized administrator of DigitalCommons@University of Nebraska - Lincoln. 


\title{
Late Pliocene diatoms in a diatomite from Prydz Bay, East Antarctica
}

\author{
Albert D. Mahood ${ }^{1}$ and John A. Barron ${ }^{2}$ \\ ${ }^{1}$ California Academy of Sciences, Golden Gate Park, San Francisco, California, 94118-9961 U.S.A. \\ ${ }^{2}$ U.S. Geological Survey MS 915, Menlo Park, California, 94025 U.S.A.
}

\begin{abstract}
Very well-preserved Pliocene diatoms from a diatomite unit interbedded within glacial sediments at Ocean Drilling Program Site 742 in Prydz Bay, Antarctica are documented and illustrated. The presence of Thalassiosira kolbei, T. torokina, Actinocyclus actinochilus, A. karstenii and the absence of Nitzschia interfrigidaria. T. insigna and T. vulnifica in Sample 119-742A-15R-4, 44-46cm constrain its age to ca. 2.2-1.8 Ma (late Pliocene). Diatoms associated with sea ice constitute $35 \%$ of the Pliocene diatom assemblage, compared with $71 \%$ of the modern sediment assemblage at the site, suggesting that sea ice was present during the late Pliocene period of deposition of the sample, although it probably was not the significant feature it is today.

Thalassiosira ellitipora (Donahue) Fenner is described and illustrated in detail and is validly published. An expanded description and numerous illustrations are also presented for T. torokina Brady.
\end{abstract}

\section{INTRODUCTION}

During Ocean Drilling Program Leg 119 on the continental shelf in Prydz Bay, Antarctica, a 60-cm-thick unit of distinctive greenish gray to gray diatomite (lithologic Subunit IIIB) was recovered within a thick $(300+\mathrm{m})$ sequence of coarse-grained glacial diamictite in Core $15 \mathrm{R}$ of Hole $742 \mathrm{~A}$ at $67^{\circ} 32.98^{\prime} \mathrm{S}$, $75^{\circ} 24.27 \mathrm{E}$ and a water depth of $426.2 \mathrm{~m}$ (text-fig. 1) (Shipboard Scientific Party 1989). The abundant Pliocene diatoms found in this diatomite were apparently deposited during a period of enhanced biologic productivity in a distal glaciomarine setting. possibly during an interglacial period warmer than today (Shipboard Scientific Party 1989). The presence of well-preserved Pliocene diatoms within otherwise glacial sediments that typify the Antarctic shelf is relatively rare and offers an opportunity to study a nearshore environment of East Antarctica during an interval of the late Pliocene. A study of the diatoms of this Pliocene diatomite may provide evidence that bears on the hypothesis of Webb et al. (1984) and Webb and Harwood (1991) that calls for large scale deglaciation of East Antarctica during parts of the early and late Pliocene. In addition, the well-preserved nature of the diatoms in this deposit allows their study under the scanning electron microscope(SEM) and may contribute to solving some of the numerous problems of taxonomic confusion that currently plagues the study of Pliocene Antarctic diatoms (Harwood and Maruyama 1992).

\section{MATERIALS AND METHODS}

Sample 119-742A-15R-4, 44-46cm was collected from the $60 \mathrm{~cm}$-thick diatomite unit. The sample was processed for light microscopy (LM) and SEM by the Van der Werff (1955) hydrogen peroxide method. Strew slides were mounted in Hyrax for LM with individual species ringed for identification and photographic reference. Examination of taxa was made using a Leitz Ortholux II and an Olympus IMT at magnifications of $\times 500$ and $\times 1250$. SEM examination and photography was made using a Cambridge 250 mark II SEM at the U.S. Geological Survey (Menlo Park) and a Hitachi S520 at the California Academy of
Sciences. Diatom terminology follows that of Ross et al. (1979). Sample material (CAS number 613278, ODP 119-742A-15R-4, $44-46 \mathrm{~cm}$ ) and slides (CAS numbers 217016-217018, 217022, $217026,217027,217029)$ are deposited at the California Academy of Sciences.

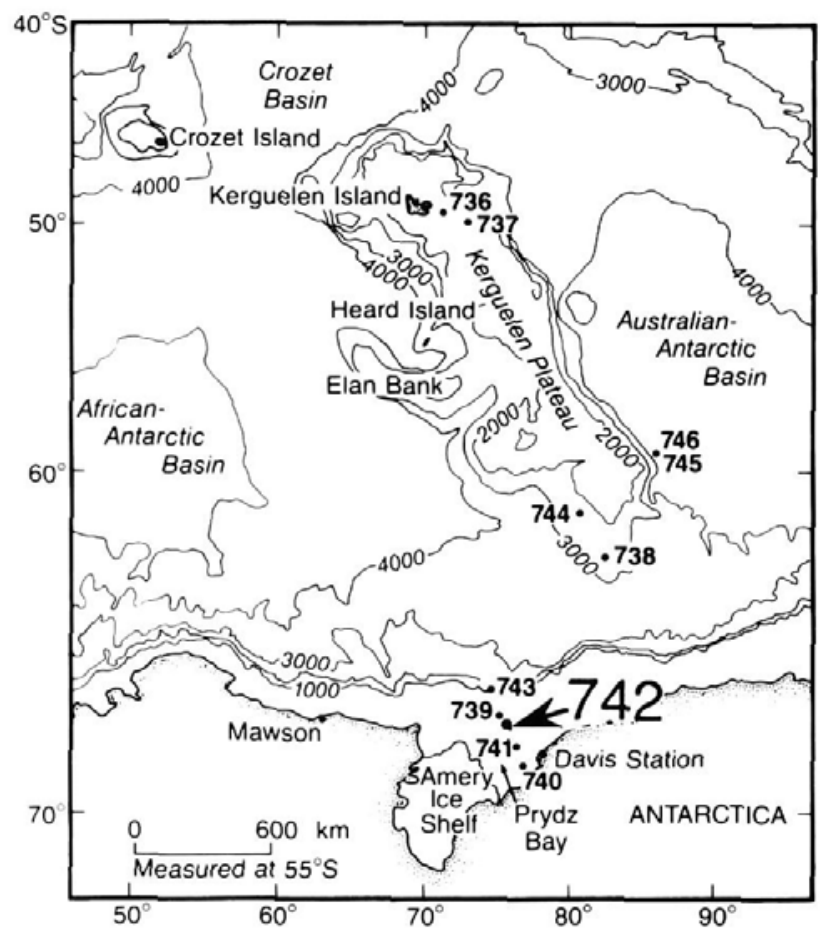

TEXT-FIGURE 1

Location of ODP Site 742 in Prydz Bay, East Antarctica, and other sites cores by ODP Leg 119. Contours in meters. 
TABLE 1

Tabulation of diatom taxa in Pliocene Sample ODP-119-742A-15R-4, $44-46 \mathrm{~cm}$ and their relative percentage compared with the relative percentage of taxa recorded in surface sediment at the site by Stockwell et al. $(1991){ }^{*}=$ extinct; ()$=$ possible decendent.

\begin{tabular}{|c|c|c|c|}
\hline \multirow[t]{2}{*}{ Taxon } & \multicolumn{2}{|c|}{ Pliocene sediment } & \multirow{2}{*}{$\begin{array}{c}\text { Modem sediment } \\
\%\end{array}$} \\
\hline & \# valves & $\%$ & \\
\hline Actinocyclus actinochilus & 16 & 3.7 & 0.7 \\
\hline A. ingens & 14 & 3.3 & $*$ \\
\hline A. karstenii & 3 & 0.7 & * \\
\hline A.sp. & 1 & 0.2 & 0 \\
\hline Diploneis sp & 1 & 0.2 & 0 \\
\hline Eucampia antarctica & 14 & 3.3 & 0.13 \\
\hline Fragilariopsis obliquecostata & 67 & 15.7 & 6.2 \\
\hline Nitzschia barronii & 13 & 3.0 & $(2.1)$ \\
\hline Rhizosolenia styliformis & 7 & 1.6 & 0 \\
\hline R.sp. D & 5 & 1.2 & * \\
\hline R.sp. & 13 & 3.0 & 0.3 \\
\hline Rouxia antarctica & 65 & 15.2 & $*$ \\
\hline R. diploneides & 25 & 5.9 & $*$ \\
\hline Stellarima microtrias & 52 & 12.2 & 0.7 \\
\hline Thalassiosira elliptipora & 7 & 1.6 & $*$ \\
\hline T. kolbei & 2 & 0.5 & $*$ \\
\hline T. lentiginosa & 17 & 4.0 & 0.5 \\
\hline T. oliverana var. 1 & 1 & 0.2 & 0 \\
\hline T. oliverana var. 2 & 6 & 1.4 & 0 \\
\hline T. oliverana var. 3 & 2 & 0.5 & 0 \\
\hline T. oliverana var. 4 & 7 & 1.6 & 0 \\
\hline T. tetraoestrupii & 5 & 1.2 & 0 \\
\hline T. tetraoestrupii var. reimeri & 19 & 4.4 & 0 \\
\hline T. torokina & 47 & 11.0 & $*$ \\
\hline Thalassiothrix spp. & 18 & 4.2 & 0 \\
\hline total & 427 & 100 & 10.63 \\
\hline \multicolumn{4}{|c|}{ Additional modem taxa with a Pliocene record: } \\
\hline Fragilariopsis curta & 0 & 0 & 55.7 \\
\hline F. cylindrus & 0 & 0 & 7.5 \\
\hline Thalassiosira spore & $?$ & $?$ & 5.5 \\
\hline
\end{tabular}

\section{RESULTS}

\section{Diatom Assemblage}

The diatom taxa identified in Sample 119-742A-15R-4, 44$46 \mathrm{~cm}$ are listed in the Appendix and figured in part in the plates. Selected remarks are included about the morphology and taxonomy of the taxa. Their known ecology or inferred paleoecology is included.

The frequency of these taxa in a random count of 427 individuals is given in Table 1, where it is compared with similar counts in Holocene (modern) sediment from ODP Site 742 (after
Stockwell et al. 1991). Disregarding the extinct taxa present in the Pliocene sample, the major difference between the late Pliocene and Holocene diatom assemblages is the dominance of the sea ice associated diatom Fragilariopsis curta (Van Heurck) Hasle in the latter and its complete absence in the former. Fragilariopsis cylindrus (Grunow) Hasle, another sea ice diatom which makes up $7.5 \%$ of the Holocene assemblage, is also absent from the Pliocene sample. Nitzschia praecurta Gersonde, a probable ancestor of $F$. curta according to Gersonde (1990), is present in the Pliocene sample (Appendix); however, it is so rare that it was not recorded in the count (Table 1). Fragilariopsis curta and F. cylindrus are recorded elsewhere in the Southern Ocean in Pliocene sediments (Gersonde and Burckle 1990; Baldauf and Barron 1991; Harwood and Maruyama 1992), so their absence in Sample ODP 119-742A-15R-4, 44-46cm may not be due to the Pliocene age of the sediment. The common occurrence of other finely-silicified Nitzschia and Rouxia taxa in the Pliocene sample would suggest that the absence of $F$. curta and $F$. cylindrus was not due to dissolution, implying that their absence may be due to reduced amounts of sea ice (Pichon et al. 1987; Stockwell et al. 1991). On the other hand, a number of the diatoms in the Pliocene assemblage do have modern associations with sea ice or the plankton near sea ice (Table 1 and notes in Appendix), namely Fragilariopsis obliquecostata (Van Heurck) Hasle, Eucampia antarctica (Castracane) Mangin, Actinocyclus actinochilus (Ehrenberg) Simonsen, and Stellarima microtrias (Ehrenberg) Hasle et Sims. These sea ice related diatoms account for nearly $35 \%$ of the Pliocene diatom assemblage in Sample 119-742A-15R-4, 44-46cm, compared with approximately $71 \%$ of the modern sediment assemblage at the site (Table 1). This suggests that sea ice was present in the vicinity of Site 742 during the late Pliocene period of deposition of the sample although probably not as important a feature as it is in the modern environment of the site.

\section{Age}

The presence of Thalassiosira kolbei (Jousé) Gersonde, $T$, torokina Brady, Actinocyclus actinochilus, and A. karstenii Van Heurck, along with the absence of Nitzschia interfrigidaria McCollum, T. insigna (Jousé) Harwood et Maruyama and T. vulnifica (Gombos) Fenner in Sample 119-742A-15R-4, 44-46cm constrain its age to ca. 2.2-1.8 Ma (late Pliocene)(Harwood and Maruyama 1992). According to Harwood and Maruyama (1992), the presence of $T$. elliptipora in this sample seems to indicate an age younger than 1.6 Ma; however, Baldauf and Barron (1991) stated that this taxon has its first occurrence immediately after the last occurrence of T. vulnifica (2.2 Ma) in ODP Hole 119-736A (text-fig. 1), an observation supported by the
1,2,3 Eucampia antarctica (Castracane) Mangin. 1, scale bar $=10 \mu \mathrm{m} ; 2$, scale bar $=20 \mu \mathrm{m} ; 3$, scale bar $=10 \mu \mathrm{m}$.

45 Rhizosolenia sp. D of Harwood and Maruyama, 1992. $4 \mathrm{a}$, scale bar $=2 \mu \mathrm{m}$, apex of fig. $4 \mathrm{~b} ; 4 \mathrm{~b}$, scale bar $=$ $10 \mu \mathrm{m} ; 5 \mathrm{a}$, base of fig. $5 \mathrm{~b}$, scale bar $=10 \mu \mathrm{m} ; 5 \mathrm{~b}$, scale bar $=10 \mu \mathrm{m}$.
6 Cocconeis costata var. antarctica Manguin. scale bar $=10 \mu \mathrm{m}$.

7 Rhizosolenia styliformis Brightwell. scale bar $=10 \mu \mathrm{m}$. 

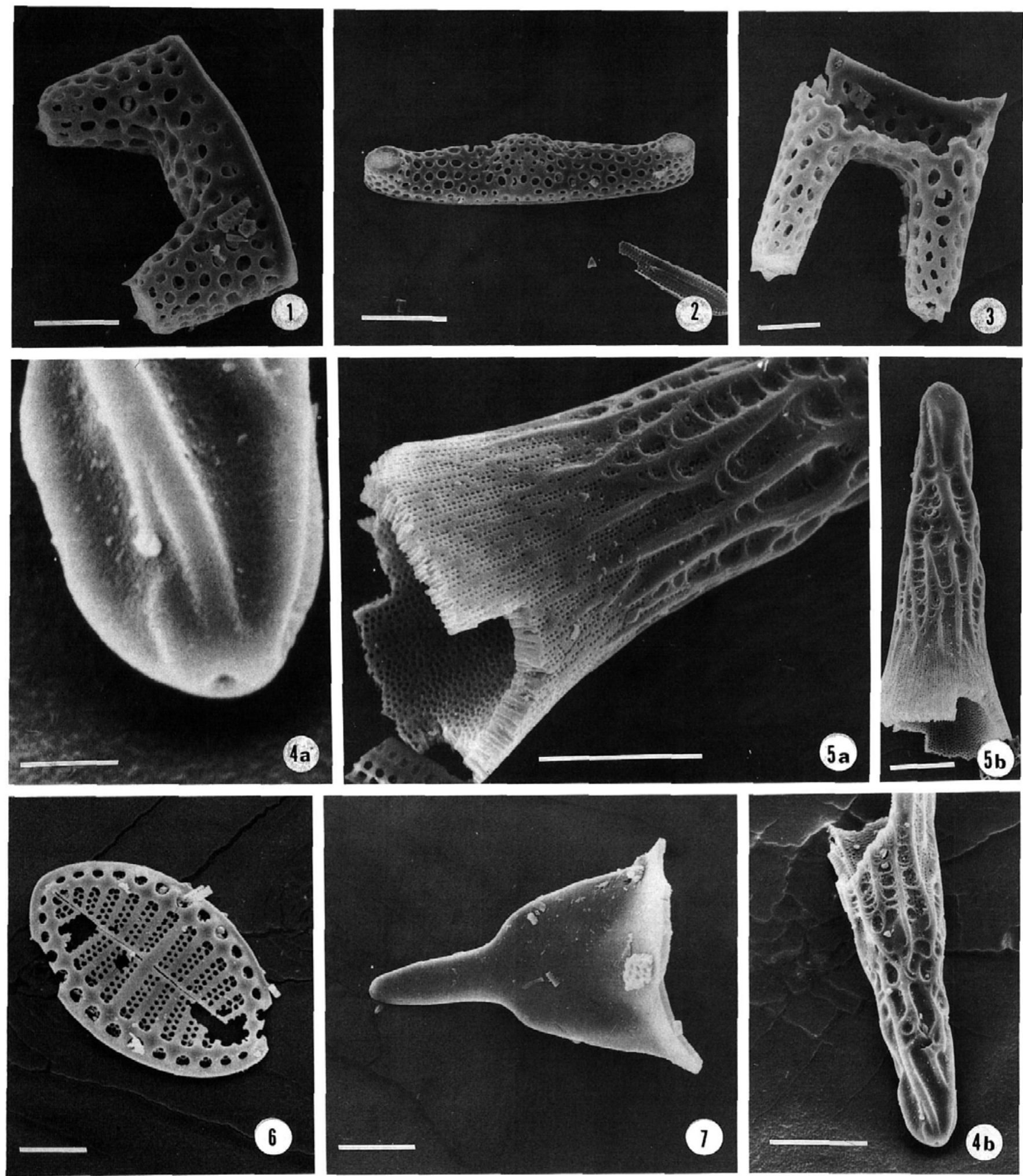

(4b) 
junior author in selected deep-sea cores of the Southern Ocean (Barron, unpublished data).

\section{ACKNOWLEDGMENTS}

This paper benefitted from the reviews of David Harwood, Lloyd Burckle, Greta Fryxell, and Scott Starratt. We would like to acknowledge the use of the California Academy of Sciences diatom library and facilities. Robert Oscarson of the U.S. Geological Survey and Darrell Ubick from the California Academy of Sciences assisted in the SEM photography. Kevin Purcell of the U.S. Geological Survey assisted in the LM photography. Special thanks are given to G.A. Fryxell of the Texas A\&M University, D.M. Harwood of the University of Nebraska and J.P. Kociolek of the California Academy of Sciences for their helpful comments. The Ocean Drilling Program is thanked for contributing the sample.

\section{APPENDIX}

Taxonomic remarks and floral references. Original, recent and easily available references are given for each identified species.

Actinocyclus actinochilus (Ehrenberg) Simonsen

Plate 7, figure 22

Actinocyclus actinochilus (Ehrenberg) SIMONSEN 1982, p. 101-116, pl. 1-4. - VILLAREAL AND FRYXELL 1983, p. 461, fig. 21-32.

Charcotia actinochilus (Ehrenberg) HUSTEDT 1958, p. 122, pl. 7, figs. $57-80$

Actinocyclus sp. cf. A. actinochilus (older form) sensu HARWOOD

AND MARUYAMA 1992, pl. 12, fig. 9-11).

See Simonsen (1982) for full list of synonyms.

Remarks: Usually seen with eroded mantle. As Simonsen (1982), we found that A. actinochilus displayed a continuum of variations in the central area from hyaline to many areolae as well as variations in the number and density of fascicles similar to the illustrations of Hustedt (1958, pl. 7, figs. 57-80). Examination of a slide prepared from material from the Challenger Expedition, courtesy of the British Museum, prepared by A. Truan, "January (19)68" has helped to verify this species. The Challenger sample, Exp $3 / 31874,53^{\circ} 55^{\prime} \mathrm{S}, 105^{\circ} 35^{\prime} \mathrm{W}$ from a depth of $3672 \mathrm{~m}$ was listed as ocean glacial.

Ecology: Fenner et al. (1976) reported this species as Charcotia actinochilus (Ehrenberg) Hustedt, and noted that it was restricted to Antarctic surface waters. Hargraves (1968) found it to be abundant in the pack-ice zone.

Actinocyclus fasciculatus Harwood and Maruyama

Actinocyclusfasciculatus HARWOOD and MARUYAMA 1992, p. 700, pl. 13, figs. 14,15 .
Remarks: Rare, not recorded in Table 1.

Actinocyclus ingens Rattray

Plate 3, figures $1 \mathrm{a}-4$; plate 7, figures 20a, 20b, 21

Actinocyclus ingens RATTRAY 1890, p. 149, pl. 11, fig. 7. - GERSONDE 1990, pl. 1, fig. 7, pl. 3, fig. 8, 9, pl. 6, fig.1. - BALDAUF AND BARRON 1991, p. 58, pl. 5, fig. 2. - HARWOOD AND MARUYAMA 1992, p. 700, pl. 8, fig. 10, pl. 11, figs. 4, 6, pl. 12, fig. 8.

Remarks: This species displays considerable variation in the number of radiating rows, fascicles and number of areolae within a row.

Paleoecology: Fenner (1991) reported that A. ingens inhabited both subantarctic and Antarctic surface waters during the late Pliocene and early Pleistocene and inferred that it may have been most common beneath the Polar Frontal Zone (PFZ).

\section{Actinocyclus karstenii Van Heurck}

Plate 3, figure 5

Actinocyclus karstenii VAN HEURCK 1909, p. 44, pl. 12, fig. 158. HARWOOD AND MARUYAMA 1992, p. 700, pl. 13, figs. 1, 2, 6-8, 10,11 and 13 .

Remarks: Although specimens that are clearly referable to $A$. karstenii were rarely encountered, the variation in row density, characteristic hyaline space at the margin and alternating radiating rows of areolae, many specimens suggest a similarity to A. actinochilus. A clear separation of A. karstenii and A. actinochilus may not always be possible (see Harwood and Maruyama 1992, pls. 12, 13).

Asterolampra sp.

Remarks: Rare, badly eroded. Not recorded in Table 1.

Biddulphia weissflogii Grunow

Biddulphia weissflogii Grunow in VAN HEURCK 1882, pl. 100, figs. 1, 2. — JOUSÉ 1977, pl. 68, fig. 20.

Remarks: Fragment, rare. Not recorded in Table 1.

Cocconeis costata var. antarctica Manguin

Plate 1, figure 6

Cocconeis costata var. antarctica MANGUIN 1960, p. 304, pl. 14, figs. 154, 155 a-c. - FENNER ET AL. 1976, p. 771, pl. 11, fig. 12.

Remarks: very rare, not recorded in Table 1.

Ecology: Littoral taxon occurring in the plankton (Manguin 1960).

\section{PLATE 2}

1,2 Fragilariopsis obliquecostata (Van Heurck) Hasle. 1, scale bar $=10 \mu \mathrm{m}$, interior; 2 , scale bar $=2 \mu \mathrm{m}$.

3,4 Nitzschia barronii Gersonde. 3a, scale bar $=10 \mu \mathrm{m} ; 3 \mathrm{~b}$, scale bar $=2 \mu \mathrm{m}$, apex of fig. $3 \mathrm{a} ; 4$, scale bar $=10 \mu \mathrm{m}$, internal.
5,6 Rouxia antarctica Heiden. 5, scale bar $=4 \mu \mathrm{m}$, external; 6 , scale bar $=10 \mu \mathrm{m}$, internal.

7-9 Thalassiothrix sp. 7, scale bar $=4 \mu \mathrm{m}$, external; 8 , scale bar $=4 \mu \mathrm{m}$, internal; $9 \mathrm{a}$, scale bar $=4 \mu \mathrm{m}$, external, opposite end of $9 \mathrm{~b} ; 9 \mathrm{~b}$, scale bar $=4 \mu \mathrm{m}$. 

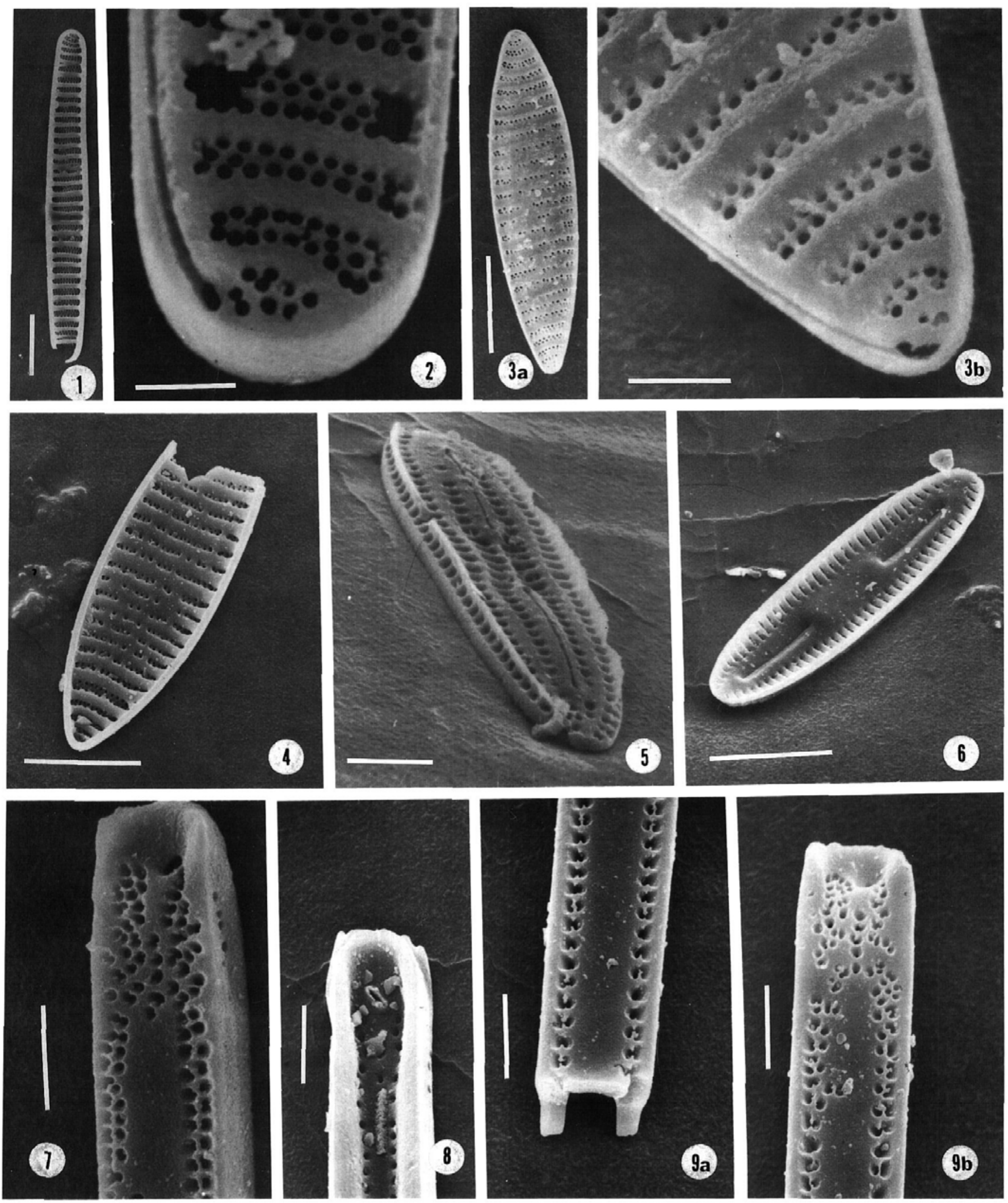

9b) 


\section{Diploneis sp.}

Remarks: A single specimen of this benthic diatom was observed.

Eucampia antarctica (Castracane) Mangin

Plate 1, figures 1-3; plate 7, figures 1, 2

Eucampia antarctica (Castracane) MANGIN 1914, p. 480, figs. 7-8. Eucampia balaustium Castracane. - MCCOLLUM 1975, p. 534, pl. 16, figs.8, 9. - FENNER ET AL. 1976, p. 774, pl. 5, figs. 7-9.

Remarks and Ecology: Fryxell and Prasad (1990) distinguish two varieties of $E$. antarctica: the type variety $E$. antarctica (Castracane) Mangin var. antarctica, which occurs north of the summer Antarctic Convergence Zone, and E. antarctica var. recta (Mangin) Fryxell et Prasad, which is truly an ice-edge diatom. Fryxell (1991) notes that unlike valves of the nominate variety, valves of $E$. antarctica var. recta tend to be larger, lack spines on the elevations and form chains that are straight in broad girdle view. We question the diagnostic value of the presence or absence of spines in fossil specimens where physical abrasion is common. We have chosen not to separate the two varieties. We note, however, that the presence of spines on figures 1 and 3 of plate 1 are indicative of E. antarctica var. antarctica. The nomenclatural history of $E$. antarctica is summarized by Fryxell et al. (1989).

Fragilariopsis obliquecostata (Van Heurck) Hasle Plate 2, figures 1, 2; plate 7, figures 9-14

Fragilariopsis obliquecostata (Van Heurck) HASLE 1965, p. 18, pl. 7, figs. 2-7. - FENNER ET AL. 1976, p. 12, figs. 15-18. - GERSONDE 1986, pl. 1, fig. 2. - GERSONDE AND WEFER 1987, pl. 4, fig. 5.

Remarks: Strongly silicified, well preserved specimens of Fragilariopsis were examined and found to closely resemble $F$. obliquecostata $_{*}$ which is characterized by length $57-110 \mu \mathrm{m}$, width $8-10 \mu \mathrm{m}, 6.5-8$ costae in $10 \mu \mathrm{m}, 21-22$ intercostae poroids in $10 \mu \mathrm{m}$, and an expansion of the middle portion of the valve according to Hasle (1965). Specimens from the Pliocene sample measure as follows: length $38-64 \mu \mathrm{m}$, width $6.4-7.6 \mu \mathrm{m}, 5.5-9.8$ costae in $10 \mu \mathrm{m}$ and intercostae poroids $14-22$ (24) in $10 \mu \mathrm{m}$, which also fits the parameters of Fenner et al. (1976). The costae are only slightly oblique, as seen in the illustrations of both Hasle (1965) and Fenner et al. (1976).

Because most of the Fragilariopsis have been described from Recent material (Hustedt 1958; Hasle 1965), not all descriptive characteristics can be used when evaluating the fossil record. Fragilariopsis is described by Round et al. (1990) as "usually united in flat ribbon-like colonies", a characteristic rarely useful in stratigraphic studies. Age in itself is not a species characteristic although there is evidence that some species described from recent material, morphologically identically under the LM, are distinctly different from fossil material when careful SEM is used. A number of the Fragilariopsis, including F kerguelensis (O'Meara) Hustedt, F. obliquecostata, F curta, F. cylindrus and $F$. linearis (Castracane) Frenguelli, from fossil material appear to be morphologically identical to the recent forms when viewed under LM and have been listed as such. It is apparent that more careful studies like Gersonde (1991) are needed to clarify the taxonomic differences between fossil and recent species of very similar morphology.

With this discussion in mind we have chosen to use $F$. obliquecostata as the species name until more extensive evaluation of the specimen can be made.

Ecology: Although various authors (Hustedt 1958; Hasle 1965; Fenner et al. 1976) report a rather widespread distribution of $F$. obliquecostata in both Antarctic and subantarctic waters. Kozlova (1962) finds this taxon to be restricted to the Antarctic coastline and waters lying near the ice edge. Based on her study of siliceous microorganisms recovered from sea ice and from surface sediment in the southern Weddell Sea, Gersonde (1986) concluded that $F$. obliquecostata may be a useful guide species for a neritic environment that is strongly influenced by sea ice, supporting Kozlova's (1962) conclusion.

Nitzschia barronii Gersonde

Plate 2, figures 3a, 3b, 4; plate 7, figures 16,17

Nitzschia barronii GERSONDE 1991, p. 146, pl. 3, fig. 6, pl. 4, fig. 1-3, pl. 5, figs. 7-17. - GERSONDE AND BURCKLE 1990, p. 78, pl. 1, figs. 11-13. - HARWOOD AND MARUYAMA 1992, p. 704, pl. 17, figs. 27, 28.

Remarks: This species shows considerable variation in length, width and shape. Gersonde (1991) remarks that $N$. barronii differs from $N$. angulata (O'Meara) Hasle by its distinctly coarser strial structure and the presence of hyaline, non-perforated areas on the valve face.

Paleoecology: Abelmann et al. (1990) suggest that $N$. barronii preferred Antarctic waters, a hypothesis also favored by Barron (in press).

Nitzschia praecurta Gersonde

Plate 7, figure 15

\section{PLATE 3}

1-4 Actinocyclus ingens Rattray. 1a, scale bar $=5 \mu \mathrm{m}$, frustule; 1b, valvocopula (arrow) of 1a; 2 , scale bar $=$ $10 \mu \mathrm{m}$, external, valvocopula; 3 , scale bar $=10 \mu \mathrm{m}$, external; 4 . scale bar $=10 \mu \mathrm{m}$, internal, labiate processes (arrows).
5 Actinocyclus karstenii Van Heurck. 5, scale bar = $20 \mu \mathrm{m}$, external, pseudonodule (arrow).

6-7 Stellarima microtrias (Ehrenberg) Hasle and Sims. 6a, scale bar $=20 \mu \mathrm{m}$, frustule; $6 \mathrm{~b}$, scale bar $=4 \mu \mathrm{m}$, central area of $6 a$, external labiate aperture (arrow); 7, scale bar $=10 \mu \mathrm{m}$, internal, labiate processes (arrows). 

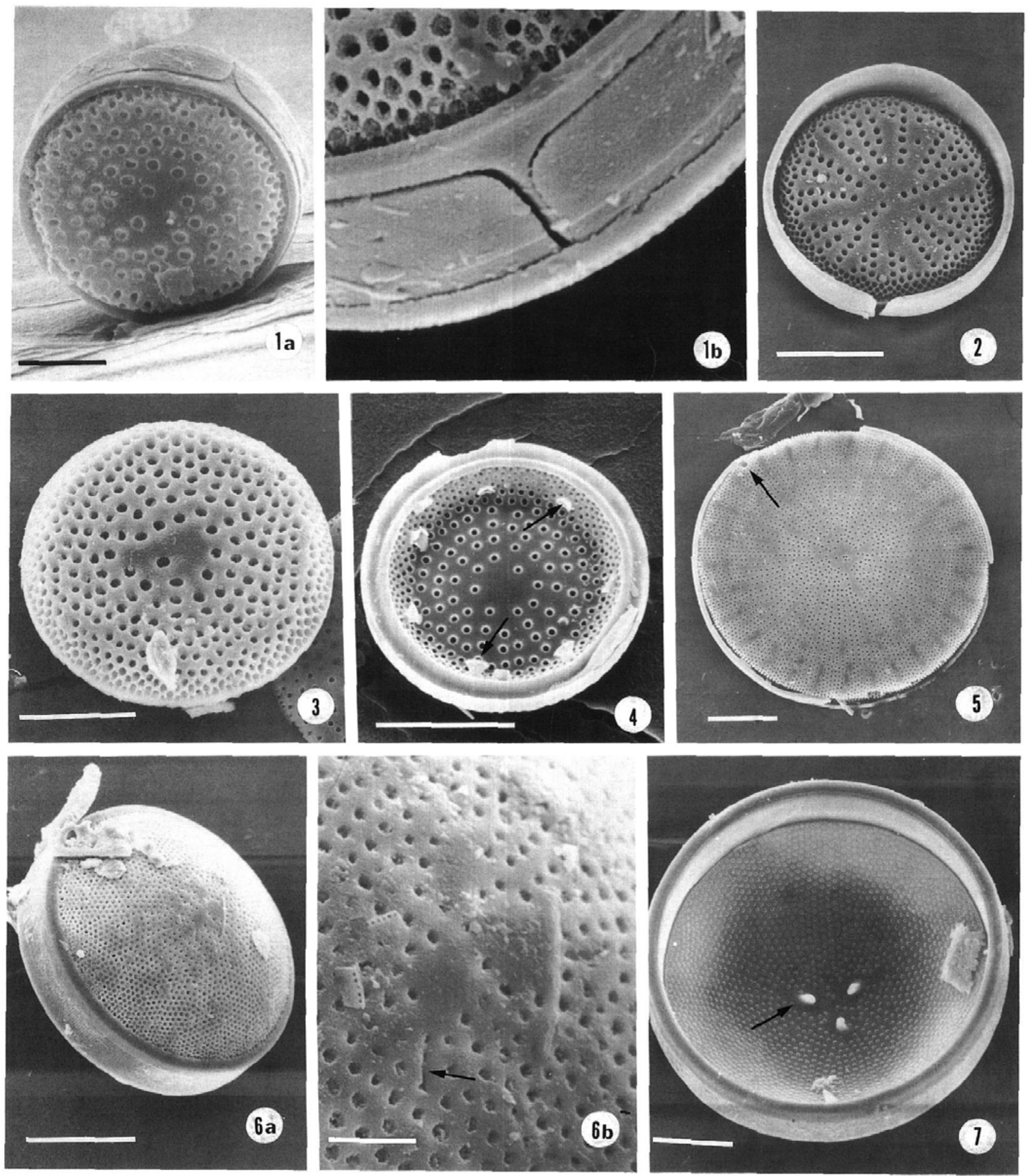
Nitzschia praecurta GERSONDE 1991. p. 148, pl. 1, figs. 7-17; pl. 2, fig. 5,6 ; pl. 3 , fig. 3,4 ; pl. 10 , fig. 7 .

Remarks: Rare, not recorded in Table 1. Apicies rounded, three apical costae turned towards the apex. Gersonde suggests $N$. praecurta is a precursor of $N$. curta (Nitzschia curta $=$ Fragilariopsis curta). As discussed under $F$. obliquecostata, until a detailed SEM study is made of the Fragilariopsis, their taxonomic position is in question. Harwood and Maruyama (1992) list the last occurrence of $N$. praecurta at $3.6 \mathrm{Ma}$, substantially older than the estimated age of Sample 119-742A-15R-4, 44$46 \mathrm{~cm}(2.2-1.8 \mathrm{Ma})$.

\section{Rhizosolenia hebetata f. bidens Heiden}

Plate 7 , figure 8

Rhizosolenia hebetata f. bidens Heiden in HEIDEN AND KOLBE 1928. - FENNER ET AL., 1976, p. 778, pl. 13, fig. 8. — JOUSÉ 1977, pl. 8 , fig. 18 as $R$. spp.

Remarks: Rare, not recorded in Table 1.

Ecology: Fenner et al. (1976) reported this taxon from both Antarctic and subantarctic waters but note that it had its maximum abundance in the region of the PFZ.

\section{Rhizosolenia hebetata f. hiemalis Gran}

Plate 7, figures 5, 7

Rhizosolenia hebetata f. hiemalis GRAN 1905, p. 527, pl. 27, fig 9; FENNER ET AL., 1976, p. 778, pl. 13, figs. 10-12.

Remarks: Rare, not recorded in Table 1.

Ecology: Fenner et al. (1976) reported this taxon from both Antarctic and subantarctic waters but note that it had its maximum abundance in the region of the PFZ.

Rhizosolenia styliformis Brightwell

Plate 1, figure 7; plate 7 , figures 4,7

Rhizosolenia styliformis Brightwell. - FENNER ET AL. 1976, p. 779. pl. 13, figs. 3-5, 9. - HARWOOD AND MARUYAMA 1992, p. 705, pl. 18, fig. 20.

Ecology: Fenner et al. (1976) notes that $R$. styliformis is generally reported to be a cosmopolitan species. She recorded it in both Antarctic and Subantarctic waters.

Rhizosolenia sp. D

Plate 1 , figures $4 a, 4 b, 5 a, 5 b$; plate 7 , figure 3
Rhizosolenia sp. D of HARWOOD AND MARUYAMA 1992, p. 705 , pl. 18, figs. 7-10.

Remarks: The robust apical end of this distinctive diatom contains irregularly-shaped areolae that are separated by prominent marginal ridges (pl. 1, figs. $4 \mathrm{~b}, 5 \mathrm{a}, 5 \mathrm{~b}$ ). These ridges are twisted around the apical horn in a screw-like fashion (pl 1, figs. 4b, $5 b)$.

Rouxia antarctica Heiden

Plate 2, figures 5, 6, plate 7, figures 18,19

Rouxia antarctica Heiden in HEIDEN AND KOLBE 1928, p. 632, pl. 4 fig. 90. - MCCOLLUM 1975, p. 535, pl. 11, figs. 11-12. - HARWOOD AND MARUYAMA 1992, p. 705, pl. 18, fig 24.

Remarks: Abundant (Table 1).

Rouxia diploneides Schrader

Rouxia diploneides SCHRADER 1973, p. 710, pl. 3, figs. 27-32. HARWOOD AND MARUYAMA 1992, p. 705, pl. 17, fig. 12.

Remarks: Common but usually broken.

Stellarima microtrias (Ehrenberg) Hasle and Sims

Plate 3, figures 6a, 6b, 7

Stellarima microtrias (Ehrenberg) HASLE and SIMS 1986, p. 111, figs. 18-27. - HARWOOD 1989, p. 80, pl. 1, fig. 3 .

Coscinodiscus furcatus KARSTEN 1905, p. 82, pl. 4, fig. 7- HUSTEDT 1958, p. 113, pl. 3, figs. 18, 19.

Coscinosira stellaris (Roper) Heiden var. symbolophora (Grun.) HEIDEN and KOLBE, p. 471.

Ecology: According to Hasle et al. (1988), S. microtrias is confined to Antarctic waters and is particularly common on or in shelf-ice or in the surrounding plankton.

Thalassiosira elliptipora (Donahue) Fenner ex Mahood and Barron Plate 4, figure 3 ; plate 5 , figures $4 a-7 c$; plate 8 , figure 6

Thalassiosira elliptipora (Donahue) Fenner ex Mahood and Barron, herein. - FENNER 1991, pp. 104 and 108, pl. 1, fig. 3, pl. 3, fig. 2. - HARWOOD AND MARUYAMA 1992, p. 707, pl. 16, fig. 12.

Coscinodiscus elliptipora DONAHUE 1970, p. 183, pl. 4, figs. e, i-m. MCCOLLUM 1975, p. 526, pl. 16, fig. 10. - GOMBOS 1977, p. 592, pl. 3 , figs. $1-3,6$, pl. 9 , fig. 3 .

Validation: Coscinodiscus elliptipora Donahue, was described in an unpublished (and difficult to obtain) Ph.D. dissertation (Donahue 1970) and is therefore invalid under Article 29 of the International Code of Botanical Nomenclature. It is also invalid because Donahue (1970) failed to designated a type (Art. 37,
PLATE 4

1,2 Thalassiosira kolbei (Jousé) Gersonde. 1, scale bar = $20 \mu \mathrm{m} ; 2$, scale bar $=20 \mu \mathrm{m}$, internal.

3 Thalassiosira elliptipora (Donohue) Fenner ex Mahood and Barron. scale bar $=20 \mu \mathrm{m}$, internal.

45 Thalassiosira lentiginosa (Janisch) G. Fryxell. 4a, scale bar $=20 \mu \mathrm{m}$, internal, labiate process (small arrow), strutted process depressions (large arrow); $4 \mathrm{~b}$, scale bar $=2 \mu \mathrm{m}$, internal, margin of fig. $4 \mathrm{~b}$, strutted process depression (arrow); 5, scale bar $=20 \mu \mathrm{m}$, labiate aperture (arrow).

6-7 Thalassiosira tetraoestrupii var reimeri Mahood and Barron. 6a, scale bar $=10$, labiate aperture (small arrow), central depression with strutted process aperture (large arrow); $6 \mathrm{~b}$, scale bar $=2 \mu \mathrm{m}$, labiate process (small arrow), central strutted process aperture (large arrow); 7 , scale bar $=10 \mu \mathrm{m}$. labiate process (small arrow), central strutted process (large arrow). 

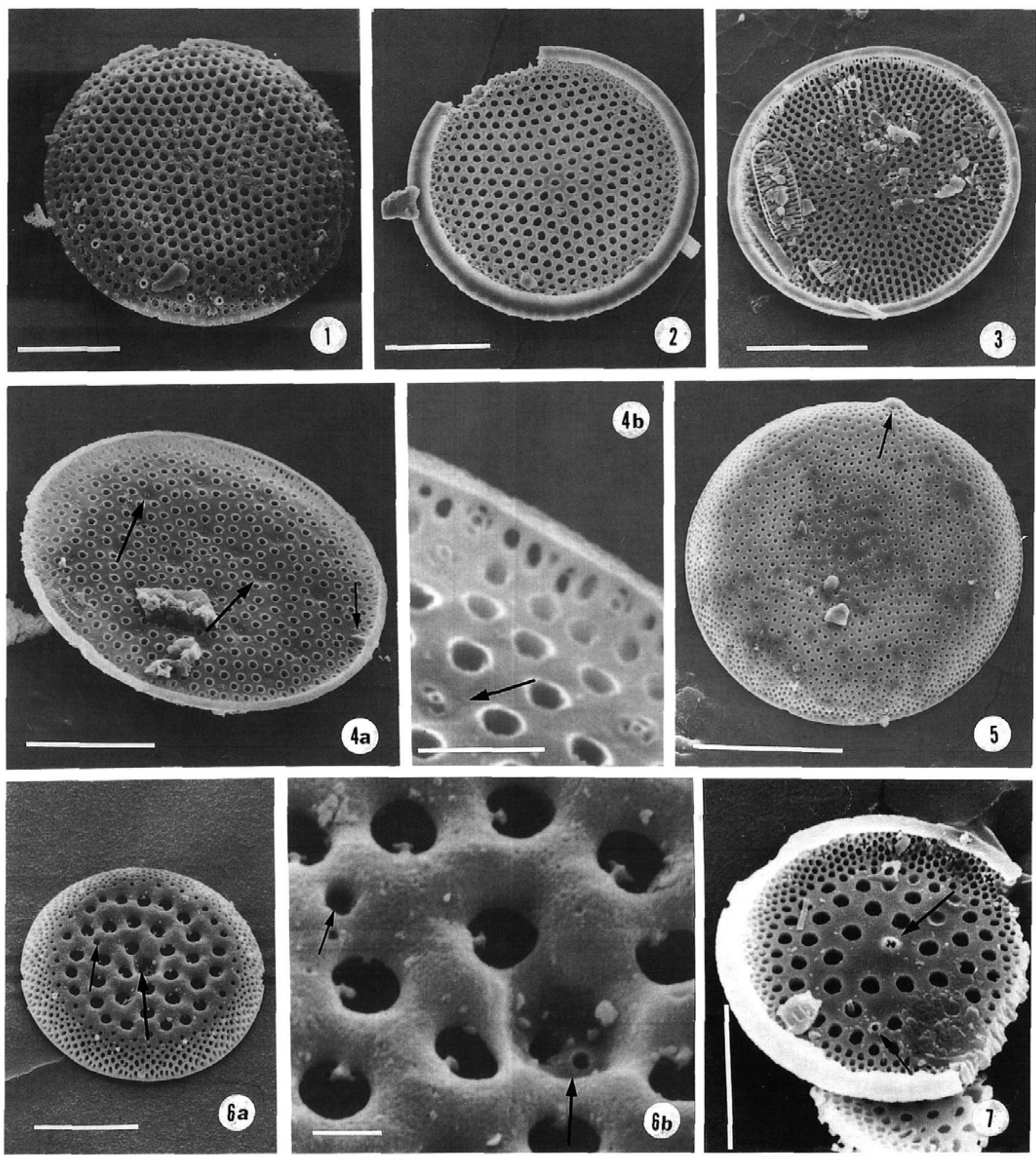
ICBN). This taxon has been recognized and illustrated by numerous subsequent authors (see Fenner 1991; Harwood and Maruyama 1992); however, only Harwood and Maruyama (1992) have questioned its legitimacy. These authors suggested (Harwood and Maruyama 1992, p. 707) that Coscindiscus planisculus Rattray 1890 may have priority over $C$. elliptipora Donahue. Although Rattray's drawing (1890, pl. I, fig. 22) of $C$. planisculus does resemble C. elliptipora with its elliptical, radiating areolae, Rattray (p. 42) cites as the source of his illustration figure 12 of plate VI of Janisch's 1888 unpublished manuscript on diatoms from the Gazelle Expedition. Examination of a phographic copy of Janish's (1888) excellent plates at the California Academy of Sciences reveals that figure 12 of plate VI is closer in appearance to Thalassiosira vulnifica (Gombos) Fenner and is definitely not comparable with $C$. elliptipora.

The occurrence of excellently preserved specimens referable to C. elliptipora sensu Donahue 1970 in Sample 119-742A-15R$42-44 \mathrm{~cm}$ offers the opportunity to validly publish and illustrate this taxon. Because it has been widely used, we have chosen to preserve the original epithet.

Description: Valve circular and flat, ranging in diameter from about 45 to $90 \mu \mathrm{m}$. The species is characterized by fasciculated areolae (pl. 5, figs. $4 \mathrm{a}, 5,6 \mathrm{a}, 7 \mathrm{~b})(5-7$ in $10 \mu \mathrm{m}$ toward the center) that develop an elongated, elliptical shape toward the valve's margin (pl. 5, fig. 4a, 6a, 6b). A distinctive T-shaped external labiate process (pl. 5, figs. 4b, 6b) is present on the margin; however, due to the elaborate and fragile external areolae at the margin (pl. 5, figs. 4a, 5, 6a, 7c), the interior margin is frequently missing from the valve. In well preserved specimens, strutted processes are scattered over the valve face (pl. 5, figs 7a, 7b, $7 \mathrm{c}$ ), where they take the place of areolae in a manner reminiscent of T. lentiginosa (Janisch) G. Fryxell.

Holotype: Plate 8, figure 6, CAS 217029, Sample 119-742A15R-42-44cm, Prydz Bay, East Antarctica.

Isotype: Plate 8, figure 7, CAS 217018.

Remarks: Fenner (1991) observed a variety of T. elliptipora in which only the areolae just above the margin are elongated ranging older and younger than the peak abundance of the more characteristic forms of $T$. elliptipora which have elongated areolae throughout the valve. Gombos (1977) noted and illustrated the variation in the ellpticity of the pores and noted that the elliptical areolae may be present only on the margins.
From the same Challenger slide described under the Actinocyclus actinochilus, observations were made of a valve that matches the description for T. elliptipora. The areolae on this valve are clearly elliptical, fasciculated across the whole valve face. The margin was missing in a manner similar to valves in this sample.

Paleoecology: Fenner's (1991) studies suggest that this endemic Southern Ocean species was most common in northern Antarctic surface waters, but it also was found within the PFZ and in subantarctic surface waters.

T. kolbei (Jousé) Gersonde

Plate 4, figures 1, 2; plate 8 , figures $1 \mathrm{a}, 1 \mathrm{~b}$

T. kolbei (Jousé) GERSONDE 1990, p. 793, pl. 1, fig. 2, pl. 5, figs. 3, 5, 6. - GERSONDE AND BURCKLE 1990, p, 782, pl. 3, fig. 1 .

Coscinodiscus kolbei Jousé. - MCCOLLUM 1975, p. 527, pl. 4, figs. 7-9.

Remarks: Valve flat, distinctive eccentric pattern, robust external marginal strutted processes and prominent poroid areolae. A strutted processes between most valve face areolae.

Rare.

Paleoecology: Fenner (1991) believes that T. kolbei was endemic to the Southern Ocean and preferred subantarctic surface waters.

T. lentiginosa (Janisch) G. Fryxell

Plate 4, figures $4 \mathrm{a}, 4 \mathrm{~b}, 5$; plate 8 , figures $2 \mathrm{a}, 2 \mathrm{~b}$

T. lentiginosa (Janisch) G. FRYXELL 1977, p. 100, figs. 13a-14d. HARWOOD AND MARUYAMA 1992, p. 707, pl. 19. fig. 8.

Coscinodiscus lentiginosus Janisch in SCHMIDT ET AL. 1878, pl. 58, fig. 11.

Remarks: The morphological structures of $T$. lentiginosa, a recent species present "south of the Antarctic Convergence" (Fryxell 1977) and T. lentiginosa from this sample differ only in the internal silica structure surrounding the strutted processes. Each of the internal valve strutted processes is set within a distinctive depression (pl. 4, figs. 4a, 4b). The internal valve of Fryxell's T. lentiginosa is flat and level surrounding the strutted processes (Fryxell 1977, figs. 14a, 14b, and 14c).

Ecology: Fenner et al. (1976) report T. lentiginosa (as Coscinodiscus lentiginosus Janisch) in both subantarctic and Antarctic waters, but note that maximum abundances occur in Antarctic waters.

\section{PLATE 5}

1-3 Thalassiosira oliverana (O'Meara) Makarova and Nikolaev. 1 , scale bar $=10 \mu \mathrm{m}$, labiate aperture (small arrow), valve face strutted process apertures (large arrows); 2, scale bar $=10 \mu \mathrm{m}$, valve face strutted process apertures (arrows); 3 , scale bar $=10 \mu \mathrm{m}$, internal.

47 Thalassiosira elliptipora (Donahue) Fenner ex Mahood and Barron. 4a, scale bar $=10 \mu \mathrm{m}$, elongated marginal areolae; $4 \mathrm{~b}$, scale bar $=2 \mu \mathrm{m}$, labiate aperture (arrow); 5 , scale bar $=20 \mu \mathrm{m}$, external, random strutted processes; $6 \mathrm{a}$, scale bar $=20 \mu \mathrm{m}$, fasciculated areolae, labiate aperture (arrow); $6 \mathrm{~b}$, scale bar $=5 \mu \mathrm{m}$, elongate mantle areolae, labiate aperture (arrow); 7a, scale bar $=5 \mu \mathrm{m}$, internal margin of $7 \mathrm{~b}$, strutted process (small arrow); $7 \mathrm{~b}$, scale bar $=20 \mu \mathrm{m}$, internal, labiate process (arrow); $7 \mathrm{c}$, scale bar $=4 \mu \mathrm{m}$, internal, margin at labiate process (large arrow), strutted process (second arrow). 

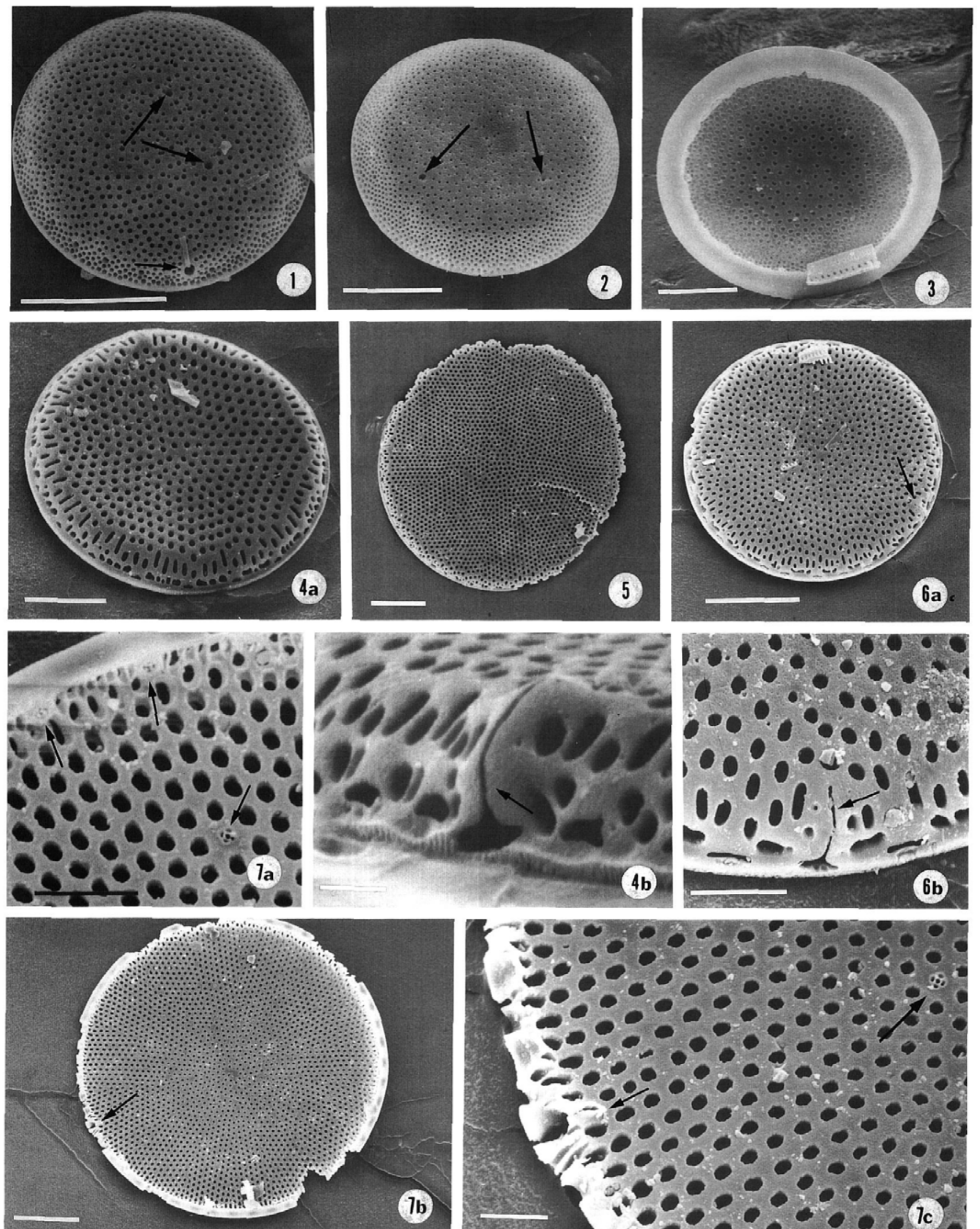

(7b)

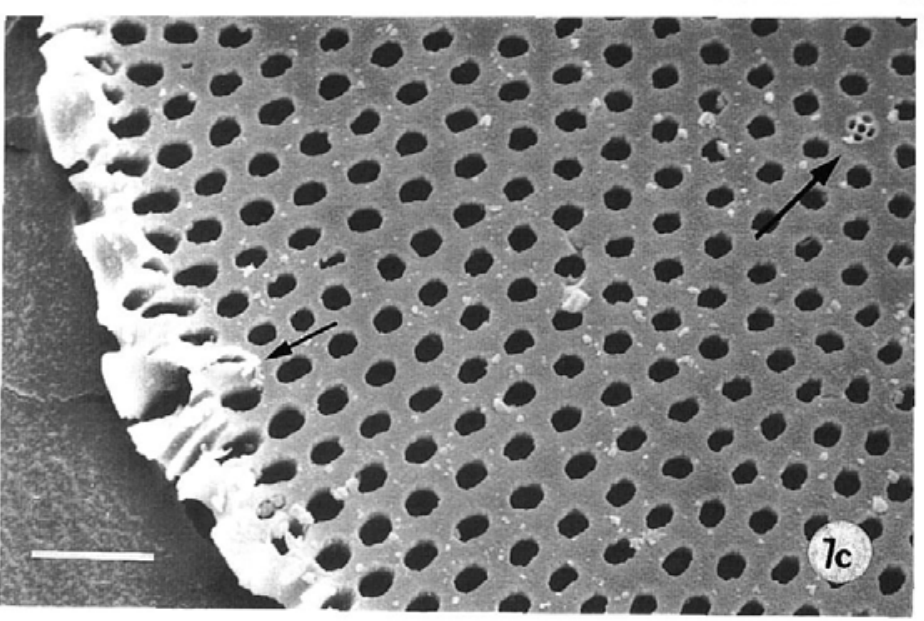


T. oliverana (O'Meara) Makarova and Nikolaev

Plate 5, figures $1,2,3$; plate 8 , figures $3,4,5$

T. oliverana (O'Meara) MAKAROVA and NIKOLAEV 1984, p. 89, pl. 1, figs. 1-11, pl. 2, figs. 1-11. - GERSONDE AND BURCKLE 1990, p. 782. - HARWOOD and MARUYAMA 1992, p. 708, pl. 14, figs. $1,2,6,7,11,17$.

Schimperiella antarctica KARSTEN 1905, p. 88, fig. 6.

Remarks: This is a highly variable species and is presently under investigation by David Harwood and his students (personal communication, 1994). In Table 1 we have listed four variations of $T$. oliverana based on the number of areolae present in the central hyaline area, which typically occupies less than one third of the diameter of the valve: variety 1 , clear; variety $2,1-4$ areaolae; variety 3, 5-10 areolae; variety 4, filled with areolae but less dense than the center of the valve. If these forms represent winter growth stages, morphological variations might reflect different conditions (G. Fryxell, written comm., 1995).

Ecology: Fenner et al. (1976) record this taxon (as S. antarctica) in both subantarctic and Antarctic waters, with a maximum abundance in the PFZ.

\section{T. tetraoestrupii Bodén 1993}

T. tetraoestrupii Bodén 1993, p. 63, pl. 1, figs. A-G, pl. 2, figs. A, B, H, J. - MAHOOD AND BARRON, in press, figs. 9-19, 25, 26, 28-46.

Remarks: Bodén (1993) determined that the characteristics describing $T$. oestrupii (Ostenfeld) Hasle, a recent species, were different than those of fossil species referred to T. oestrupii, although they were of very similar appearance under LM. Bodén's SEM (1993) studies of fossil forms clearly demonstrated that the strutted processes at the margin and central area have four satellite pores rather than three as found in the recent form. Secondly, Bodén (1993) found the margin of the fossil species to have more areolae in $10 \mu \mathrm{m}$ than that of the recent species. It is important to note that neither of these characteristics, satellite pores and marginal areolae, can be seen easily in fossil material. Mahood and Barron (in press) comment on the presence of $T$. tetraoestrupii in Pliocene material from the Southern Ocean.

T. tetraoestrupii var. reimeri_Mahood and Barron

Plate 4, figures $6 \mathrm{a}, 6 \mathrm{~b}, 7$, plate 8 , figures 9-12

T. tetraoestrupii var. reimeri_MAHOOD and BARRON (in press), pl. 4, figs. $6 a, 6$ b, 7, pl. 8, figs. 9-12.
Remarks: T. tetraoestrupii Bodén (Bodén 1993) exhibits a wide spread variability in number of areolae across the valve face, pattern change at the valve face-mantle interface and the relative placement of the central strutted process and labiate process. $T$. tetraoestrupii var reimeri is easily distinguished from other forms of T. tetraoestrupii by its distinct central depression (plate 4 , figures $6 \mathrm{a}, 6 \mathrm{~b}, 7$, plate 8 , figures 9-12) which contains the central strutted process. See Bodén (1993) and Mahood and Barron (in press) for a thorough discussion.

T. torokina Brady 1977

Plate 6 , figures $1 \mathrm{a}-3 \mathrm{c}$; plate 8 , figure 8

T. torokina BRADY 1977, pp. 122-123, figs. 1-5. - HARWOOD 1986, p. 87 , pl. 8 , figs. 2,3 .

T. gerloffii? RAMIREZ 1981, pp. 73-82, pls. 26-28, figs. 164-177.

Remarks: Expanded description; Valve circular, convex, 37 to $45 \mu \mathrm{m}$ in diameter (pl. 6, figs. 1a, 1b). The areolae are linear, fasciculate on valve face, $7-8$ in $10 \mu \mathrm{m}$, external poroid, internal with cribrum (fig. 3b). Valve face separated from mantle by closely abutted marginal strutted processes (pl. 6, figs. 1d, le), 10 in $10 \mu \mathrm{m}$, each with four satellite pores (pl. 6, figs. 3b, 3c). Areolae on mantle in 3-4 linear rows 10 in $10 \mu \mathrm{m}$. Central cluster of 10 to 19 strutted processes each with 3-5 satellite pores, usually 4 (pl. 6, figs. 1c, 3c). Prominent labiate process takes place of a strutted process (pl. 6, figs. 3a); external tube prominent (pl. 6, gis. 1a, 1d, 2).

In most aspects $T$. torokina and $T$. gerloffii show some striking similarities. The row of marginal strutted process in T. torokina (pl. 6, figs. 1a, 1e, 3a, 3b) and T. gerloffii (Ramirez 1981, fig. $176,172)$ are linked without an areolae separating the processes. $T$. torokina from this sample is convex and heavily silicified while $T$. gerloffii is concave (Ramirez,1981) and weakly silicified. A comparison of figures 175 and 176 (Ramirez 1981) and plate 6 , figures $1 \mathrm{a}, 1 \mathrm{~b}$, and $1 \mathrm{e}$ (this paper) show dissimilar areolae mantle patterns. (G.A. Fryxell, personal communication, 1994). Further studies will be necessary to determine synonymy if any and the relationship between the two taxa.

Thalassiothrix spp.

Plate 2, figures 7, 8, 9a, 9b

Remarks; Many specimens resemble Thalassiothrix longissima Cleve et Grunow sensu Schrader 1973, p. 713, pl. 23, figs. 7, 17, 18; Schrader 1976, p. 637, pl. 1, figs. 5-6 and 17; Harwood and Maruyama,1992, p. 708, pl. 11, fig. 12. However, the frag-
1-3 Thalassiosira torokina Brady. 1a, scale bar $=10 \mu \mathrm{m}$, $45^{\circ}$ of tilt, labiate process (white arrow), marginal strutted processes (large arrow); $1 \mathrm{~b}$, scale bar $=10 \mu \mathrm{m}$, same specimen as $1 \mathrm{a}, 20^{\circ}$ of tilt; $1 \mathrm{c}$, scale bar $=4 \mu \mathrm{m}$, center of fig. lb, cluster of central strutted process apertures (arrow); 1d, scale bar $=2 \mu \mathrm{m}$, labiate process of $1 \mathrm{a} ; 1 \mathrm{e}$, scale bar $=2 \mu \mathrm{m}$, margin of fig. $1 \mathrm{a}$, strutted process (arrow); 2 , scale bar $=2 \mu \mathrm{m}$, margin with labiate process (small arrow) and strutted processes (large arrow); $3 \mathrm{a}$, scale bar $=2 \mu \mathrm{m}$, internal, labiate process (small arrow) replacing a marginal strutted process (large arrow); $3 \mathrm{~b}$, scale bar $=1 \mu \mathrm{m}$, internal of 3a, strutted process with 4 satellite pores, cribra; $3 \mathrm{c}$, scale bar $=2 \mu \mathrm{m}$, internal of $3 \mathrm{a}$, cluster of central strutted processes with 3-5 satellite pores. 

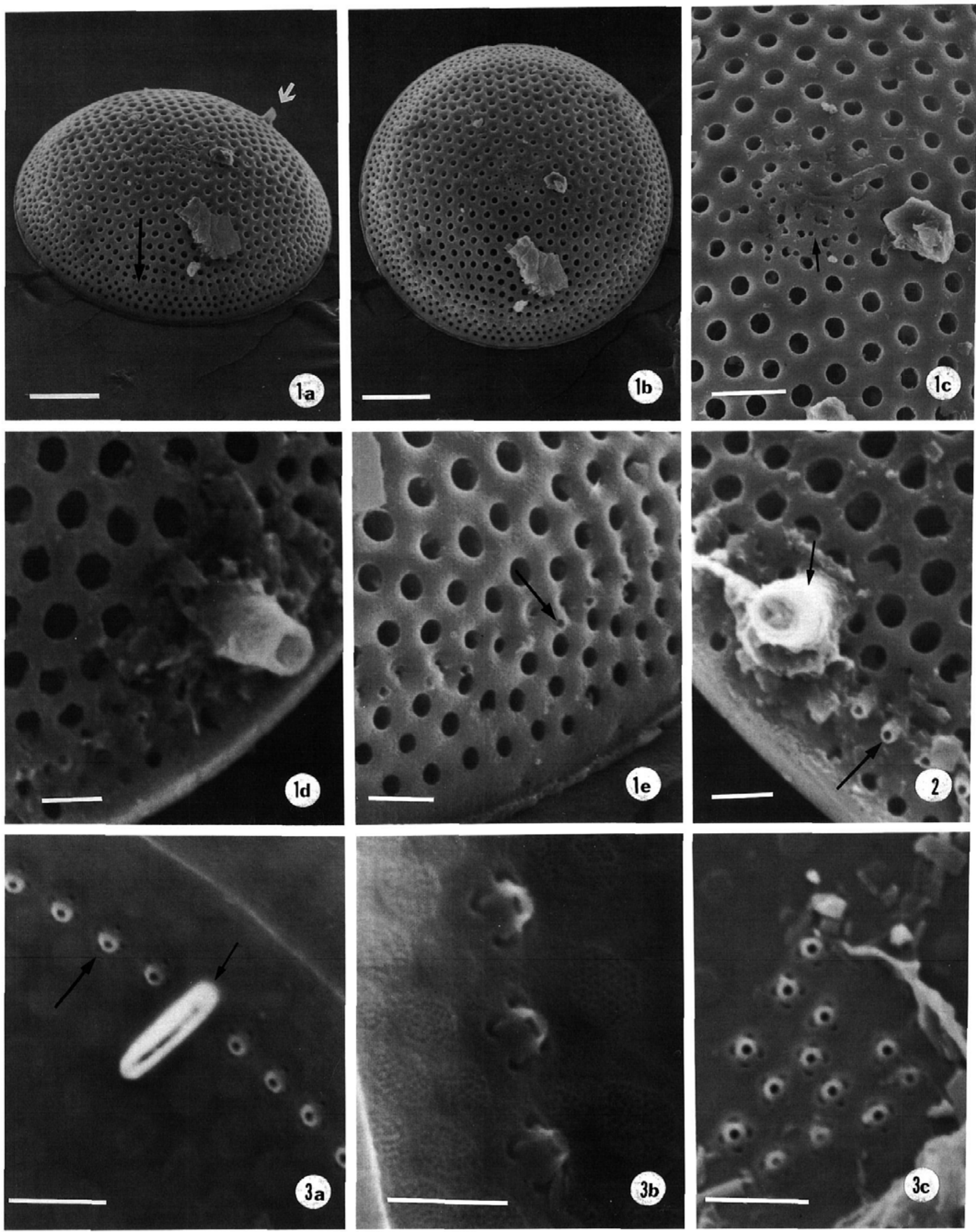
mented nature of specimens and Fenner et al.'s (1976) observation of a continuous transition between T. longissima and T. antarctica Schimper, calls for caution in assigning a specific epithet to our specimens.

Ecology: Thalassiothrix longissima is reported from both Antarctic and subantarctic surface waters by Fenner et al. (1976).

\section{REFERENCES}

ABELMANN, A., GERSONDE, R., and SPEISS, V., 1990. PliocenePleistocene paleoceanography in the Weddell Sea - siliceous microfossil evidence. In: Bleil, U., and Thiede, J., Eds., Geological History of the Polar Oceans: Arctic Versus Antarctic:729-759. Kluwer Academic Publ.: The Netherlands.

BALDAUF, J.G. and BARRON, J.A., 1991. Diatom biostratigraphy: Kerguelen Plateau and Prydz Bay regions of the southern ocean. In: Barron, J.A., Larsen, B., Baldauf, J.G., et al., Proceedings of the Ocean Drilling Program, Science Results, Volume 119:547-598. College Station, TX: Ocean Drilling Program.

BRADY, H.T., 1977. T. torokina n. sp. (Diatom) and its significance in late Cenozoic biostratigraphy. Antarctic Journal of the United States, $12: 122-123$.

BODEN, P., 1993. Taxonomy and stratigraphic occurrence of Thalassiosira tetraoestrupii sp. nov. and related species in upper Miocene and lower Pliocene sediments from the Norwegian Sea, North Atlantic and North West Pacific. Terra Nova, 5:61-75.

DONAHUE, J., 1970. Diatoms as Quaternary biostratigraphic and paleoclimatic indicators in high latitudes of the Pacific Ocean. Ph.D. dissertation, Columbia University.

FENNER, J., 1991. Late Pliocene-Quaternary quantitative diatom stratigraphy in the Atlantic sector of the Southern Ocean. In: Ciesielski, P.F., Kristoffersen, Y. et al., Proceedings of the Ocean Drilling Program, Science Results, Volume 114:97-121. College Station, TX: Ocean Drilling Program.
FENNER, J., SCHRADER, H-J, and WIENIGK, H., 1976. Diatom phytoplankton studies in the Southern Pacific Ocean, composition and correlation to the Antarctic Convergence and its Paleoecological significance. Initial Reports of the Deep Sea Drilling Project, Volume 35:757-813. Washington, D.C.: U.S. Govt. Printing Office.

FRYXELL, G.A., 1977. Thalassiosira lentiginosa (Janisch) G. Fryxell, combo. nov.: two antarctic diatoms (Bacillariophyceae) Phycologia 16(1):95-104.

, 1991. Comparison of winter and summer growth stages of the diatom Eucampia antarctica from the Kerguelen Plateau and south of the Antarctic Convergence Zone. In: Barron, J.A., Larsen, B., Baldauf, J.G., et al, Proceedings of the Ocean Drilling Program, Science Results, Volume 119:675-685. College Station, TX: Ocean Drilling Program.

FRYXELL, G.A., and PRASAD, A.K.S.K., 1990. Eucampia antarctica var. recta (Mangin) sta. nov. (Biddulphiaceae, Bacillariophyceae): life stages at the Weddell Sea ice edge. Phycologia, 29(1):27-38.

FRYXELL, G.A., PRASAD, A.K.S.K., and FRYXELL, P.A., 1989. Eucampia antarcica (Castracane) Mangin (Bacillariophyceae): complex nomclatural and taxonomic history. Taxon, 38(4):638-640.

GERSONDE, R., 1986. Siliceous microorganisms in sea ice and their record in sediments in the Southern Weddell Sea (Antarctica). In: Richard, M., ed., Proceedings of the 8th International Diatom Symposium, 549-566. Königstein, Germany: Koeltz Sci. Publ.

1990. Taxonomy and morphostruture of Neogene diatoms from Southern Ocens, ODP Leg 113. In: Barker, P.F., Kennett, J.P., et al., Proceedings of the Ocean Drilling Program, Science Results, Volume 113:791-802. College Station, TX: Ocean Drilling Program.

1991. Taxonomy and morphostructure of Pliocene diatoms from the Maud Rise (Antarctic Ocean). Polarforschung 59(3):141-171.

GERSONDE, R., and BURCKLE, L. H., 1990. Neogene diatom biostratigraphy of ODP Leg 113, Weddell Sea (Antarctic Ocean). In: Barker, P.F., Kennett, J. P., et al., Proceedings of the Ocean Drilling Program, Science Results, Volume 113:761-789. College Station, TX: Ocean Drilling Program.

\section{PLATE 7}

Scale Bar $=10 \mu \mathrm{m}$ for all figures of Plate 7

1,2 Eucampia antarctica (Castracane) Mangin. CAS 217018.

3 Rhizosolenia sp. D of Harwood and Maruyama, 1992. CAS 217016.

4,6 Rhizosolenia styliformis Brightwell. 4, CAS 217016; 6. CAS 217017.

5,7 Rhizosolenia hebetata f. hiemalis Gran. 5, CAS 217017; 7, CAS 217018.

8 Rhizosolenia hebetata f. bidens Heidens. CAS 217017.

9-14 Fragilariopsis obliquecostata (Van Heurck) Hasle. 9, CAS 217016; 10, CAS 217017; 11, CAS 217027; 12, 13, 14, CAS 217016.
15 Nitzschia praecurta Gersonde. CAS 217016.

16,17 Nitzschia barronii Gersonde. CAS 217018.

18,19 Rouxia antarctica Heiden. CAS 217027.

20,21 Actinocyclus ingens Rattray. 20a, CAS 217018, low focus; 20b, CAS 217018, high focus; 21, CAS 217027.

22 Actinocyclus actinochilus (Ehrenberg) Simonsen. CAS 217022. 

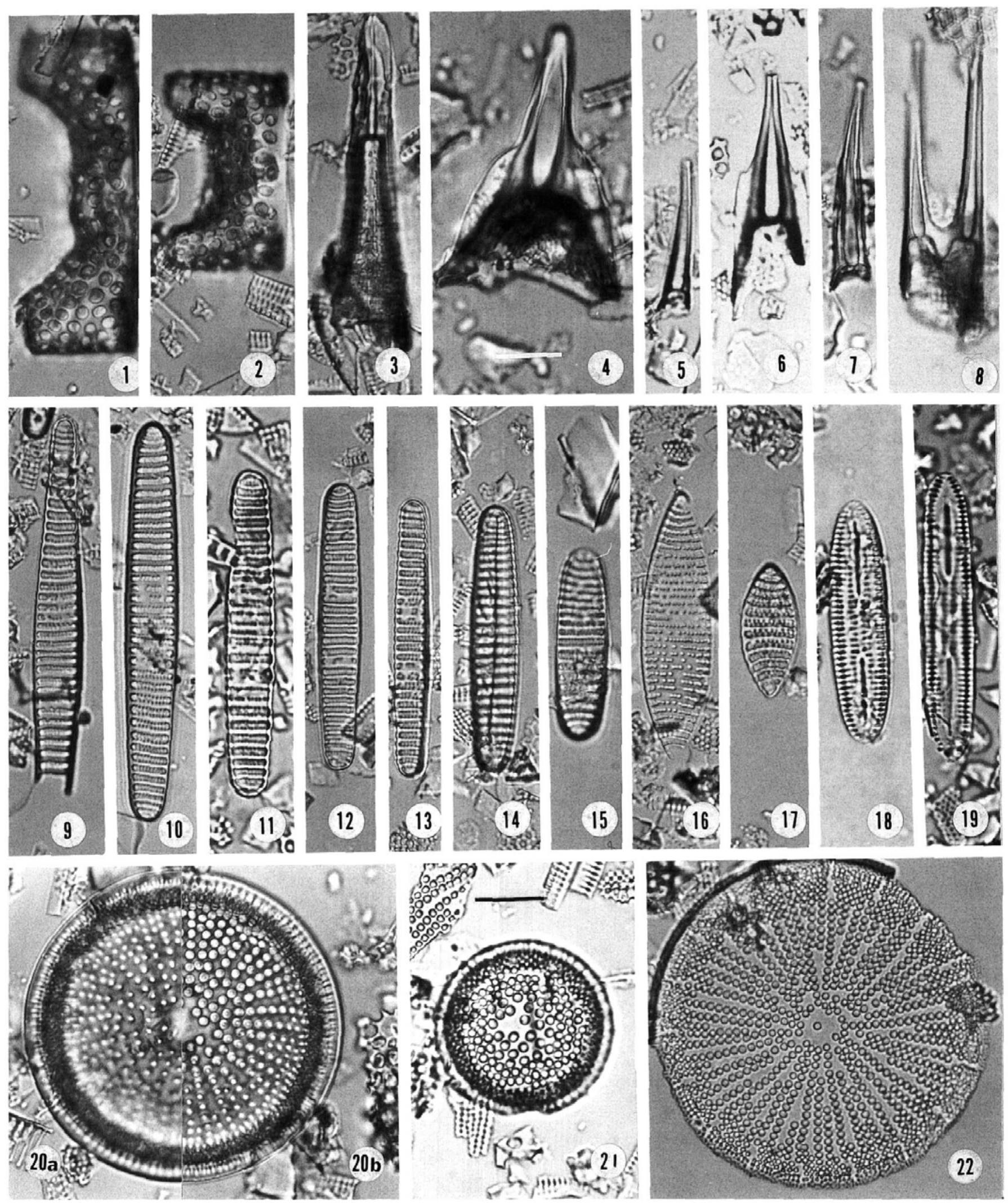
GERSONDE, R. and WEFER, G., 1987. Sedimentation of biogenic siliceous particules in Antarctic waters from the Atlantic sector. Marine Micropaleontology, 11:311-332.

GOMBOS, A.M., Jr., 1977. Paleogene and Neogene diatoms from the Falkland Plateau and Malvinas Outer Basin: Leg 36, Deep Sea Drilling Project. In: Barker, P.F., Dalziel. I.W.D., et al., Initial Reports of the Deep Sea Drilling Project, Volume 36:575-687. Washington, D.C.: U.S. Government. Printing Office.

GRAN, H., 1905. Diatomeen. In: Brandt, K. and Apstein, C., Eds., Nordische Plankton: v. 19, p. 1-146.

HARGRAVES, PAUL, 1968. Species composition and distribution of net plankton diatoms in the Pacific sector of the Antarctic Ocean. Ph.D. dissertation, College of William and Mary, Virginia, $171 \mathrm{p}$.

HARWOOD, D. M., 1986. Diatoms. In: Barrett, P.J., Ed., Antarctic Cenozoic history from the MSST-1 drillhole, McMurdo Sound. Department of Scientific and Industrial Research Bulletin, 237:69-109. Wellington, New Zealand: Department of Scientific and Industrial Research Publishing.

Siliceous microfossil biostratigraphy. In: Barrett, P.J., Ed., Antarctic Cenozoic history from the CIROS-1 drillhole, McMurdo Sound. Department of Scientific and Industrial Research Bulletin, 245:67-97. Wellington, New Zealand: Department of Scientific and Industrial Research Publishing.

HARWOOD, D. M. and MARUYAMA, T., 1992. Middle Eocene to Pleistocene diatom biostratigraphy of Southern Ocean sediments from the Kerguelen Plateau, ODP Leg 120. In: Schlich, R., Wise, S. W., Jr., Palmer, A., et al., Proceedings of the Ocean Drilling Program, Science Results, Volume 120B:683-733. College Station, TX: Ocean Drilling Program.

HASLE, G. R., 1965. Nitzschia and Fragilariopsis species in the light and electron microscopes. III. The genus Fragillariopsis. Skrifter utgitt av det Norske videnskaps-akademi i Oslo, I Matematisk-Naturvidensk Klasse, 21:5-49.

HASLE, G. R. and SIMS, P. A., 1986. The diatom genus Stellarima and Symbolophora with comments on the genus Actinoptychus. British Phycological Journal 21:97-114.

HASLE, G.R., SIMS, P.A., AND SYVERTSEN, E.E, 1988. Two Recent Stellarima species: S. microtrias and S. stellaris. Botanica Marina, 31:195-206.
HEIDEN, H., and KOLBE, R.W., 1928. Die marinnen Diatomeen der Deutschen Sudpolar-Expedition 1901-1903. In: von Dryalski, E., Ed., Deutsche Sudpolar-Expedition 101-1903. Bd. 8, Botanik, 450714.

HUSTEDT, F., 1958. Diatomeen aus der Antarktis und dem Südatlantik. Deutsche Antarkt. Expedition 1938-39, Volume 2:103-191.

JANISCH, C., 1988. Diatomacea gesammelt aur de Reise der Gazelle in 1874-1876 "Gazelle Expedition". Unpublished photographic plates (I-XXII).

JOUSE, A.P., 1977. Atlas of Microorganisms in Bottom Sediments of the Oceans. NAUKA Moscow. (in Russian).

KARSTEN, G., 1905. Phytoplankton des Antarrktischen Meeres nac dem Material der deutschen Tiefss-Expedition 1898-1899. Deutschen, Tiefsee-Expedition "Valdivia" 1898/99, 2(2):1-136.

KOZLOVA, O.G., 1962. Specific compostion of diatoms in the waters of the Indian sector of the Antarctic. Trudy Instituta Okeanologii, Academii Nauk SSSR, 61:3-18. (in Russian).

MCCOLLUM, D. W., 1975. Diatom stratigraphy of the Southern Ocean. In: Hayes, D.E., Frakes, L. A., et al., Initial Reports of the Deep Sea Drilling Project, Volume 28:515-571. Washington, D.C.: U.S. Govt. Printing Office.

MAHOOD, A.D.and BARRON, J.A., in press. Thalassiosira tetraoestrupii var. reimeri Mahood and Barron, nov, var., a distinctive diatom from the late Pliocene of the Southern Ocean. Reimer and Patrick Festschrift.

MAKAROVA, I.V., and NIKOLAEV, V.A., 1984. Notes on the genus Schimperiella (Bacillariophyta). Botanicheskii Zhurnal, Academii Nauk SSR, 60:87-90.

MANGIN, L., 1914. Sur le polymorphism de certaines Diatomees de l'Antarctique. Comptes Rendus Hebdomodaires Seances, Academie des Sciences Paris, 159:476-484.

, 1960. Les diatomeés de la Terre Adelie: Annals Science Naturelles, 1: 1-82.

PICHON, J.J., LABRACHERIE, M., LABEYRIE, L.D., and DUPRAT, J., 1987. Transfer functions between diatom assemblages and surface hydrology in the Southern Ocean. Palaeogeography, Palaeoclimatology, Palaeoecology, 61:79-95.

\section{PLATE 8}

Scale Bar $=10 \mu \mathrm{m}$ for all figures on plate 8 with the exception of figures 7 and 8 which are individually labeled.

1 Thalassiosira kolbei (Jousé) Gersonde. CAS 217026. $1 \mathrm{a}$, high focus; $1 \mathrm{~b}$, low focus.

2 Thalassiosira lentiginosa (Janisch) G. Fryxell. CAS 217026. 2a, low focus; $2 \mathrm{~b}$, high focus.

3-5 Thalassiosira oliverana (O'Meara) Makarova and Nikolaev. 3a, CAS 217027, high focus; 3b, CAS 217027 , low focus; $4 \mathrm{a}$. CAS 217018 , high focus; $4 \mathrm{~b}$. CAS 217018, low focus; 5a, CAS 217027, high focus; 5b. CAS 217027, low focus.
6,7 Thalassiosira ellitipora (Donahue) Fenner ex Mahood and Barron. 6, Holotype, CAS 217029; 7, scale bar $=10$, Isotype, CAS 217018.

8 Thalassiosira torokina Brady. scale bar $=10$, CAS 217018.

9-12 Thalassiosira tetraoestrupii var. reimeri Mahood and Barron. Central depressed areolae with strutted process (arrow). 9, CAS 217016; 10, CAS 217027; 11, CAS 217017; 12, CAS 217022. 


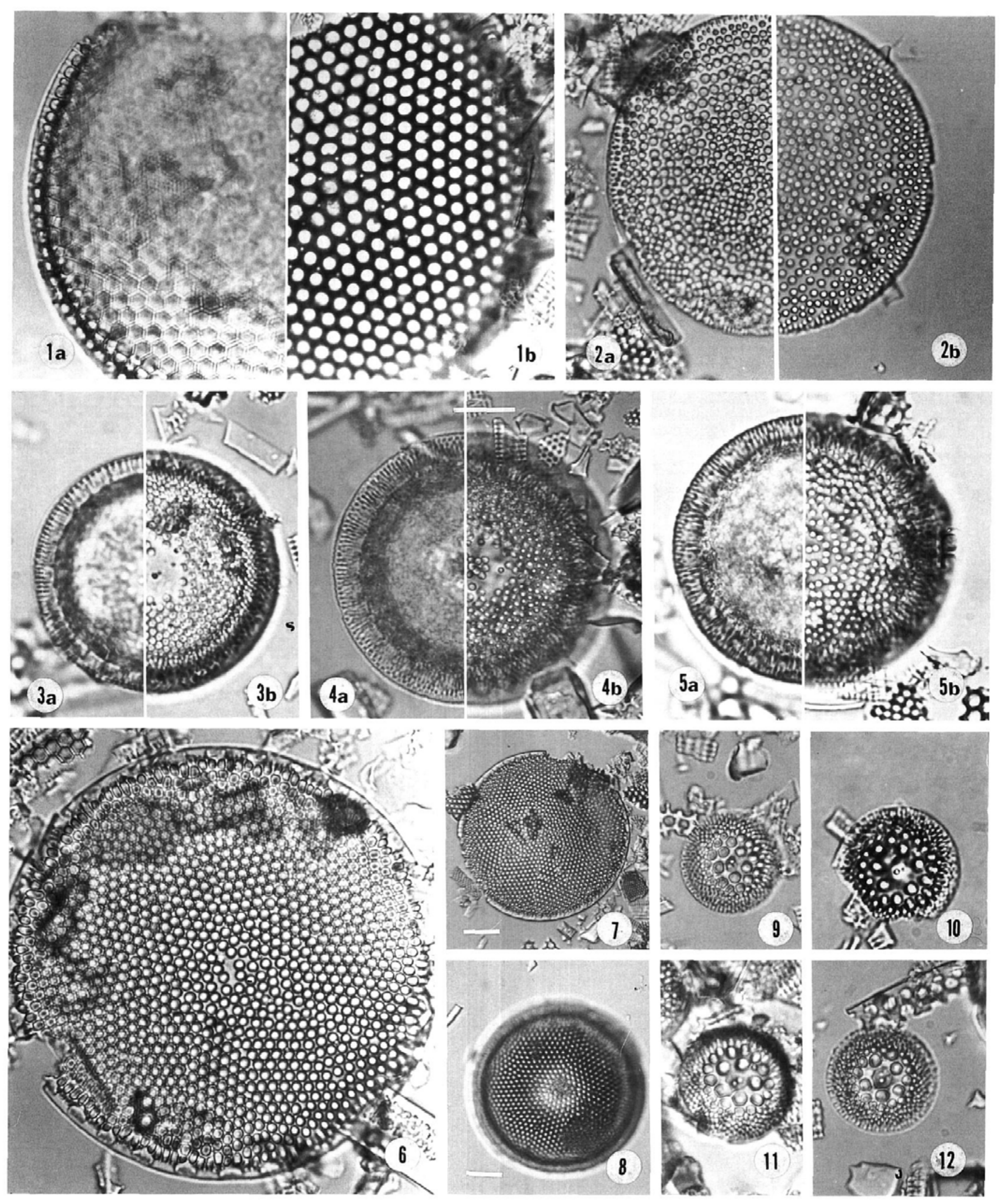


RAMIREZ, P.R., 1981. Beitrage zur Taxonomie und Verbreitung der Gattung Thalassiosira Cleve (Bacillariophyceae) in den Kustengewassern Chiles. Bibliotheca Phycologica 56:73-82.

RATTRAY, J., 1890. Revision of the genus Coscinodiscus and some allied genera. Proc. R. Soc. Edinburgh, 16:449-692.

ROSS, R., COX, E.J., KARAYEVA, N.I.,MANN, D.G., PADDOCK, T.B.B., SIMONSEN, R., and SIMS, P.A., 1979. An amended terminology for the siliceous components of the diatom cell. Nova Hedwigia. Beiheft 64:513-533.

ROUND, F.E., CRAWFORD, R.M. AND MANN, D.G., 1990. The Diatoms. Biology and Morphology of the Genera. Cambridge University Press, Cambridge, 747 p.

SCHMIDT, A. et al., 1874-1959. Atlas der Diatomaceen-Kunde, Tafeln 1-480. Leipzig, Germany: O.R. Reisland.

SCHRADER, H.J., 1973. Cenozoic diatoms from the northeast Pacific, Leg 18. In: Kulm, L.D.., von Huene, R., et. al., Initial Reports of the Deep Sea Drilling Project, Volume 18:673-797. Washington, D.C.: U.S. Govt. Printing Office.

, 1976. Cenozoic planktonic diatom biostratigraphy of the Southern Pacific Ocean. In: Hollister, C.D., Craddock, C., et al., Initial Reports of the Deep Sea Drilling Project, Volume 35:605-672. Washington, D.C.: U.S. Govt. Printing Office.

SIMONSEN, R., 1982. Note on the diatom genus Charcotia M. Peragallo Bacillaria, 5: 101-116.

SHIPBOARD SCIENTIFIC PARTY, 1989. Site 742. In: Barron, J.A., Larsen, B., et al., Proceedings of the Ocean Drilling Program, Science
Results, Volume 119:397-458. College Station, TX: Ocean Drilling Program.

STOCKWELL, D.A., KANG, S.-H., and FRYXELL, G.A., 1991. Comparison sof diatom biocoenoses with Holocene sediment assemblages in Prydz Bay, Antarctica. In: Barron, J.A., Larsen, B., Baldauf, J.G., et al, Proceedings of the Ocean Drilling Program, Science Results, Volume 119B:667-673. College Station, TX:Ocean Drilling Program.

VAN DER WERFF, A., 1955. A method of concentrating and cleaning diatoms and other organisms. International Association of Theoretical and Applied Limnology Proceedings, 12:276-277.

VAN HEURCK, H., 1882. Synopsis des Diatomeed de Belgique. Atlas, pl. 100, figs 1,2. Ducaju and Cie., Anveres.

1909. Expedition Antarctic Belge. Resultats du Voyage du S.Y. "Belgica" en 1897-1899, Botanique, Diatomees: Anvers (J.E. Buschmann).

VILLAREAL, T.A. and FRYXELL, G.A., 1983. The genus Actinocyclus (Bacillariophyceae): frustule morphology of A. sagittulus sp. nov. and two related species Journal of Phycology 19:452-466.

WEBB, P.-N., HARWOOD, D.M., MCKELVEY, B.C., MERCER, J.H. AND STOTT, L.D., 1984. Cenozoic marine sedimentation and icevolume variation on the East Antarctic craton. Geology, 12:287-291.

WEBB, P.-N. AND HARWOOD, D.M., 1991. Late Cenozoic glacial history of the Ross Embayment, Antarctica. Quaternary Science Reviews, 10:215-223.

Manuscript received June 9, 1995

Manuscript accepted September 23, 1995 